\title{
THE LAW SCHOOL: RECOLLECTIONS AND THOUGHTS FOR THE FUTURE
}

\author{
Thomas Eichelbaum*
}

This paper was presented as a lecture on "Capital Law School Day" organised by the New Zealand Institute of Advanced Legal Studies to mark the occasion of the centenary of the Faculty of Law, Victoria University of Wellington in 1999.

Those making the arrangements, the entirely admirable arrangements, for this Seminar may not have known that His Excellency, Sir Michael Hardie Boys and I commenced our law studies on the same day. That is understandable, given the continued youthful vigour of His Excellency in body and mind. However, regarding our student days we necessarily cover the same period, so I will have to do my best not to be repetitive. Incidentally, His Excellency was modest in excluding himself from the ranks of the really bright ones. He was the Senior Scholar in our class, and one of the early editors-in-chief of the University Law Review.

His Excellency's reminiscences will have kindled your memories, as they have mine. I recall the Law Library's move to a separate room, which at the start my friend Eric Freeman and I guarded on alternate evenings. Eric, now retired after serving as Ombudsman in Western Australia, is in the audience today.

The perspective from which I speak, then, is of a student in the early post-war era and of a part-time lecturer in the period soon after completing my degree. In both respects I feel my experience was reasonably typical.

The custom then developing was to do the first year of study full time. In that year we were supposed to obtain an overview of a legal system by studying Roman Law. Since neither the substance nor the procedure of the Roman system bore much resemblance to the English, while as His Excellency has mentioned there were certain fascinations, not the least the personality of the lecturer, personally I felt this was of limited help. The current equivalent, Laws 101, The Legal System, seems to achieve the objective in a better way and at the same time, I imagine in a manner more interesting to the students.

* GBE, Former Chief Justice of New Zealand. 
In the next three years, by taking four and sometimes five subjects a year, one could complete sufficient of the course to gain admission as a solicitor. As with most, I did that part of the course part time. From the point of view of an increase in pay, and status, and (if you were decided on becoming a litigator) gaining court experience, early admission had attractions. Even for a good student this was a heavy programme, the more so if, as was the case with most, you wanted to play sport, take part in student activities, have some social life and progress in your employment; but it was manageable. There was an obvious risk that among those competing priorities study would come last, at least until exams were approaching.

In the fifth year one could take things easy, as there were only two subjects to complete to bring up the total for the degree, which from memory comprised 19. You could then be admitted as a barrister, thus becoming a barrister and solicitor, and be capped LLB.

I try to avoid Latin phrases but one which, because of its precision, has often tended to pop up in my mind was cui bono, especially while I was Chief Justice and listened to various propositions from a variety of quarters. Who benefited by the curriculum of that era? I doubt that it brought great satisfaction to teaching members of the Faculty. From the point of view of an impecunious student, it helped, although not much at first, having regard to the pitiful salary scales of the day. My employers however, whose partner I later became, grumbled that they had to pay 32/6d for services inferior to those which only a decade or so earlier, they themselves had provided for a mere 10/- a week. But the earlier you qualified the sooner you were in a position to get something approaching a living wage.

In case all this sounds like the playing of violins, I record that the instructions were to lace our presentation with recollections from our student days.

Undoubtedly, the part-time system enabled young law clerks quickly to obtain rudimentary legal experience. There was no formal instruction equivalent to today's block courses of "professionals", although you picked up something useful in Civil Procedure and Conveyancing, two of the compulsory subjects. What else you were taught workwise depended largely on the patience of your employers - mine, I acknowledge, were extraordinarily patient. One was an expert on civil procedure and it was much easier to ask him about what was the appropriate step than look it up. Eventually he would elaborately take down his volume of Sim and say "Charging orders nisi, did you say?" at the same time leafing through the index. Given the notoriously bad index to Sim this would take some time - McGechan had not yet been written, indeed McGechan was a polite schoolboy the senior students sometimes saw at his father's home on Sunday evenings. Eventually I got the message and looked things up for myself. 
As a result of the system, by the time students finished their degree course they had had four or more years of practical experience. In a firm sufficiently large to take in one or more law clerks each year, only a year would be spent on manual and menial work such as deliveries and filing, and from then on you would graduate to real, if at first relatively trifling, legal work. As soon as you were admitted as a solicitor you could make appearances in the Magistrates Court. There you could practise your advocacy skills on minor prosecutions and on civil cases about what in today's terms now seem incredibly small amounts. I do not know how such disputes are resolved today, but certainly no law firm would now accept instructions to litigate minute problems of this kind. It was an advantage that if the budding advocate made a real hash of the case, not much harm was done to anyone.

Because of the much smaller numbers, both in the profession and of students, many law clerks had the golden opportunity of working in close proximity to an experienced lawyer, or even a leader in the profession. Thus one could absorb, partly by instruction but more often osmosis, the arts of the profession and equally importantly, its customs and ethics. Only a lucky few would be in an equivalent position today, leaving a real and, it might be thought, potentially dangerous gap in legal education which both the universities and the profession need to fill. I support those, whose numbers I know include Dean Brian Brooks, who advocate that ethics must be taught.

So the students of the day benefited in various ways but basically were on a night school regime and, despite the heroic efforts of the lecturers, obtained a night school education.

Recently, in connection with the launch of the Centennial Issue of the Law Review, I reread the late Professor McGechan's seminal 1953 article on teaching by the case method. As he emphasised, this approach demanded a considerable and sustained degree of preparation by the students and he made it clear that lack of time for preparation would not be an acceptable excuse. He said that the first student who offered that explanation in class spent the next three-quarters of an hour more or less reading the set case on his feet. Failure to have a grasp of the case, Professor McGechan threatened, would result in more cross examination, not less. Revisiting the article, I saw it served clear notice of requiring more than the average part-time student was accustomed to deliver and may have tolled the knell for part-time study.

What is the function of a law school? Professor McGechan answered: (1) to teach and train lawyers; (2) to develop legal knowledge by research and publication; and (3) to cooperate with other social sciences for the better understanding of the law and the betterment of applied social science. I am not sure today's professors would frame the prescription the same way, at the least, "teaching lawyers" would need to be interpreted so 
as to include the many who will not practise law, while "training" is now carried out mainly outside the universities.

If we are looking at the competing merits of different methods of teaching lawyers, I suppose it is a natural tendency to defend the system under which you grew up, but so far as my own legal education is concerned, I would not try to do so. In common with His Excellency, I have no doubt that the full-time approach which soon followed delivers a better educated product and is more likely to develop sound lawyers.

Is the present approach the way that will carry us through, or at least well into, the new century?

Let me digress for a moment to say that soon after I completed my studies, I found myself teaching one of the practical subjects, Civil Procedure, at eight o'clock in the morning on, as I recall, Mondays and Fridays. I say "found myself" advisedly. Procedure was a subject traditionally taught by a Chapman Tripp person. It was then taught by my mentor, friend and, later, partner Norman Morrison. He was not in good health and from time to time would ask me to take a lecture for him. This could be a bit nerve wracking; some of the students were older than I was, and if the phone call came after dinner on Sunday night, time for study of the next 15 pages of Sim was limited. Eventually I took over the teaching assignment officially. I suppose the experience stimulated what seems to have been a lifelong involvement with procedural rules.

Over the years innumerable lawyers have come up to remind me I taught them all they knew about procedure and that this did not hinder their most successful careers in commercial law or conveyancing. One student I remember vividly, partly because he attended lectures dressed in full army uniform. The lectures were in one of the old rooms with a tiered wooden floor and long heavy benches on hinges. This gentleman invariably came in late, clattered down the ten flights of steps in his hobnailed army boots, made his way to the middle of the unoccupied front row and let go the bench seat with a resounding crash. After a while I learned it was best to suspend the lecture during the entrance of that distinguished advocate of the future, Michael Bungay.

Before resuming let me return briefly to cui bono. I do not know to what extent the legal profession had a say in the approach to law teaching in the era I have been discussing, but in retrospect it may seem that the profession was the major beneficiary. It obtained a constantly renewing supply of messengers and law clerks at ridiculous rates of pay.

Coming back to the future, it was not entirely for your entertainment that I referred to my brief experience in teaching. The point is, this was a long time ago. I am not in any way qualified to speak about the future of law teaching, and certainly not in the presence of the other distinguished members of today's panel and equally distinguished audience. 
However, the prospectus for the seminar also refers to the future of the law. A contribution I possibly could make is to attempt a prediction or two about what the future holds for the practice of the law. This may be of some small help to others, better qualified than I, who will have the task of matching the educational system to the needs of the future.

One of things that has continually struck me during the course of my career is the rapidity and comprehensiveness of the changes in the subject matter of legal work since I was a student. Sir Michael has already referred to the profound nature and extent of the advances in statute and common law. As he noted, much of the contract law we were taught became overlaid by a series of statutes. The whole emphasis of torts changed with ACC legislation. Whole rafts of new specialised subjects have arisen. One can confirm this by comparing the subject index of a current volume of the New Zealand Law Reports with one taken from the 1950s, or skimming through the latest issue of the Victoria University of Wellington Law Review, where one finds subjects such as international instruments in administrative decisions, Maori fisheries, child support, matrimonial property, alternative dispute resolution and advocates compensating litigants for bringing hopeless cases. None of these, one could safely say, would have attracted a Law Review article when I was a student, nor did any of them rate as much as a mention during the courses I attended.

For the human race the great advances of the last 50 years have been founded on technology. Undoubtedly, they will continue for the next 50. As to the impact on law, in the immediate future we may see an emphasis on such topics, for example, as the legal consequences of genetic engineering, the impact of international electronic communications on contract law, the global protection of intellectual property and the resolution of transnational civil disputes. With a little ingenuity one might make a list of foreseeable future subject matter which, when grouped under convenient headings, could be made available as options in the law course.

For myself, however, I doubt this will be the path of the future. One cannot hope to teach the unforeseen and the uninvented.

Can we still recall our reactions on first reading Toffler's Future Shock, when it appeared in 1970? I suspect many thought it was ingenious but exaggerated. It referred to "the disease of change", and described persons overwhelmed by too rapid change. The human race has however proved resilient. Is there the slightest reason to think that the rate of change will decelerate? I suggest not.

For lawyers and judges, this is a challenging prospect; a frightening one if allowed to be. As a lawyer, I found that the subject matter of my caseload when I was in my 40 s bore little resemblance to what I had dealt with 20 years earlier. In my years as a Judge I found I was mainly dealing with subject matter in which I had practised little as a lawyer. 
Although I had had reasonably diverse experience of civil practice, the areas on which I had concentrated cropped up less and less in my daily judicial work. This trend I suspect will accelerate for future generations. And although this is not the point of today's discussions, it points up the need for attention to continuing education for both lawyers and the judiciary.

In switching the crystal ball to another topic, the New Zealand courts system of the future, I appreciate that only a minority of today's students will follow a career as litigators. Nevertheless, the courts are responsible for a significant proportion of the law governing the daily lives of the community. Not to take into reckoning possible future changes in the court system and how it operates would be a significant omission.

I have spoken in detail on the future shape of the court system on other occasions and of course any views I now express can only be personal ones. The Privy Council debate is a stark exception to the general speed of change. The issue has been debated endlessly without any sign of finality. Although in previous comments I have said the demise of the Privy Council appeal is inevitable, I have been wise enough, or cunning, never to predict when this might happen. The present answer is: when as a country we are able to agree on a substitute. An added complication is that, while this is true of lawyers, it is presently doubtful whether Maoridom would regard any substitute as satisfactory.

The question of a solution to the Maori component of the problem is too complex and sensitive to be debated in the time available at this moment.

Three or four main solutions are on offer to deal with the structure, should the Privy Council appeal cease to exist. For cases commenced in the High Court we could make do with a single right of appeal. That proposal, favoured in recent debate by many in the judiciary including myself, has been strongly opposed by the practising profession. We could create a new intermediate appeal court, sited between the High Court and the present Court of Appeal, the latter becoming the Supreme and final Court. Calculations have shown this would require the appointment of eight or nine more judges at the appellate level with the provision of a major new court building. Given our national resources, from a practical point of view, I regard this as an unlikely solution.

Another possibility, occasionally advanced, is some kind of Australasian court, or panPacific body, as the Supreme Court. However, assuming that the foreign judges were to be in a minority, this does little to overcome the resource implications relating to a four-tiered structure.

The remaining mainstream model is a three-tier structure in which the first level is the only court of originating jurisdiction, the High Court has appellate functions only and the Court of Appeal provides the second appeal. That was the Law Commission's proposal in 1989, during Sir Owen Woodhouse's presidency, and in a recent talk on radio Sir Geoffrey 
Palmer saw it as the likely shape of the future. I see some demerits, not the least the demise of the High Court as we know it, but it may be the only compromise capable of commanding sufficient acceptance.

I have mentioned the topic of the future court structure mainly because it is an important issue which keeps slipping into the too-hard basket. During my term of office I did not actively campaign for abolition of the Privy Council appeal, taking the view that as with wigs, such changes generally find their own right moment, with a little help. But with this subject I feel a growing sense of impatience that the right moment has been overlong in coming. Without detracting from the past value of our access to the Law Lords, for a vibrant South Pacific nation, priding itself on independence and innovation, the Privy Council link must increasingly be seen as a fine concept whose time has now passed.

I have said a little about the future subject matter that may come before the Courts and the likelihood that it will be something completely different. What about methodology? At a recent Asia-Pacific Court Conference an American speaker, Jim Dator, offered the opinion that what the public wanted was fair, speedy justice. He said they did not care whether they got it from a wigged barrister before a robed judge in a stuffy courtroom, or from a robot, or whether they settled their disputes peacefully between themselves without recourse to any third party at all.

I think that is true so far as it goes. One aspect of fairness, however, must be certainty. Another, that like cases have a like outcome. I can imagine nothing more destructive to community confidence in the justice system than departure from those principles.

The combination of adherence to a doctrine of precedent and the continued development of technology seems to carry the risk of an unmanageable overload of relevant precedents. Some years ago, before personal computers became generally available, a particularly assiduous counsel would sometimes cause amusement by citing, for example, a judgment of the District Court of Witwatersrand. In the future such material will be even more readily available than it already is. In New Zealand at any rate, so far there has been no policy about placing limitations on the scope of material of this kind the courts are prepared to receive. Even in regard to indigenous materials, we do not exclude any. Occasionally appellate judgments will caution that the case is not to be taken as a precedent, but this seems ineffective in discouraging counsel from trying to use it just for that purpose. I was known to ask counsel to read out the relevant passage in the previous judgment, in case their copy said something different from mine. I would be interested to hear from Professor Hogg and Sir Geoffrey Palmer how North America has coped with these problems. I know that in California there is a formal court rule enabling judgments to be tagged to the effect that they are not to be cited. 
We have a tradition in this country of writing judgments in such a way that they are self explanatory even to those unfamiliar with the issues. I wonder how long that can continue, especially in appellate courts. The technique enables the losing party to be satisfied that their case has received full attention, but if the system is to survive the appearances of absolute justice may have to undergo some sacrifices.

In searching back for the principles according to which law was taught when I was a student I came across a tribute Professor Ian Campbell paid to the late Professor McGechan. In referring to the case method he said its essence was to take a concrete case in all its native complexity and study the competing principles within it. One of the major tasks of law, he said, was to reconcile and integrate human ideals.

This led me to Oliver Wendell Holmes' aphorism that the law is not the place for poets or artists. The law is a calling for thinkers.

I respectfully agree with His Excellency that the prime educational requirement for successful lawyers, practising or otherwise, is a broad-based education. As to the legal content, bearing in mind that little is predictable about the specific subject headings that will be useful to the lawyer or judge of 2050 except their unpredictability, rather than try to specify any curriculum, if I were starting with a blank sheet I would devise a teaching method that helped students acquire the skills they will need regardless of the subject matter on which they are working: skills of understanding, analysing, thinking, reasoning and writing. That I am sure is what the present course structure seeks to achieve. Whether it can be enhanced I must leave to the experts.

I doubt that in this or anything else I have said I have told this distinguished and learned gathering anything you did not already know. I am proud to be one of the first century graduates of the Law Faculty of Victoria University. I have every confidence that the second century will be no less distinguished than the first. 
